\title{
MINERALOGIE KRUPNÍKOVÉHO TĚLESA V MEDVĚDÍM DOLE U KOUTŮ NAD DESNOU V JESENÍKÁCH
}

\author{
Mineralogy of a soapstone body at the locality "Medvědí důl" near Kouty nad Desnou \\ in the Jeseníky Mts.
}

\author{
Jiří Zimák', Bohuslav Fojt² , Zuzana Juránková1 \\ ${ }^{1}$ Katedra geologie PřF UP, tř. 17. listopadu 12, 77146 Olomouc; e-mail:jiri.zimak@upol.cz \\ 2 Ústav geologických věd PřF MU, Kotlářská 2, 61137 Brno; e-mail: fojt@sci.muni.cz
}

(14-24 Bělá pod Pradědem)

Key words: Silesicum, Sobotín Massif, soapstone, actinolite schist, chlorite schist, metahornblendite, chromite

\begin{abstract}
Soapstone bodies are relatively common in the Sobotín Massif in the Hrubý Jeseník Mts. (NE part of the Bohemian Massif). A small soapstone body was found near Kouty nad Desnou in the northern spur of the Sobotín Massif composed dominately of amphibolites. The soapstone body is composed of four types of rocks: i) talc schists with variable content of chlorite (clinochlore) and amphibole (actinolite, magnesiohornblende); ii) soapstone (talc + dolomite); iii) chlorite schist; iv) actinolite schist. Chromite is a typical accessory mineral of soapstone body rocks as well as metahornblendite outcropping in the locality. Studied soapstone body does not show the very distinct symmetrical internal zonation (mineralogical and petrographical) typical for well-known soapstone bodies of the Sobotín Massif (former soapstone deposits Smrčina and Zadni Hutisko). However there is no mineralogical or petrographical difference between those deposits and the studied soapstone body. Formation of the soapstone body at Kouty nad Desnou is probably connected to hydrothermal alteration of hornblendite/metahornblendite along shear zones.
\end{abstract}

Úvod

Sobotínský amfibolitový masiv v jz. části silezika je petrograficky pestrým metabazitovým komplexem. Jeho součástí jsou vedle dominantních amfibolitů, lokálně retrográdně přeměněných na zelené břidlice, a amfibolických rul také drobná krupníková tělesa víceméně čočkovitého tvaru, vykazující výraznou zonální stavbu. Jejich centrální ćást je tvořena krupníkem a mastkovou břidlicí, směrem k okraji přecházející do zóny aktinolitické (příp. tremolitické) břidlice, vnější zóna má charakter chloritické břidlice. Dvě největší a současně nejznámější $\mathrm{z}$ těchto těles (nejen $\mathrm{v}$ sileziku, ale i v rámci celé ČR) mají status př́rodní památky (PP Smrčina u Sobotína a PP Zadní Hutisko u Vernírovic). V tomto článku je mineralogicky zhodnoceno těleso vystupující $\mathrm{v}$ Medvědím dole (k. ú. Rejhotice). Jsou v něm uvedeny i nové údaje o povaze hornblenditu (metahornblenditu), jehož alterací se krupníkové těleso vytvořilo.

\section{Charakteristika lokality včetně historie výzkumu}

O mastkových břidlicích v zárezu lesní cesty vedoucí Medvědím dolem se poprvé zmiňuje Hanžl (1995), a to ve stručné zprávě o nálezu tmavě zelené ultramafické horniny, autorem označované jako hornblendit. V citované zprávě jsou uvedeny jen nejzákladnější údaje o povaze této horniny, vycházející z mikroskopického studia výbrusu v procházejícím světle a z výsledku její chemické analýzy. Z hlediska našeho článku je podstatné, že Hanžl (1995) $\mathrm{z}$ hornblenditu popisuje jemné žilky karbonátu s chloritem a mastkem. Mastkové břidlice zde podle citovaného autora vystupují na okrajích tektonické šupiny tvořené metabazity sobotínského masivu i ve střižných zónách uprostřed šupiny. Hornblendit zůstal v mastkových břidlicích zachován pravděpodobně ve formě budin (Hanžl 1995).

Fojt a Vávra (1997) v prostoru lokality makroskopicky rozlišili tři variety hornblenditu: zbřidličnatělý hornblendit (na kontaktu s „desenskou“ rulou a také podél stř̌ižných zón), všesměrně zrnitý tmavý hornblendit (zde dominantní varieta hornblenditu) a všesměrně zrnitý světlý hornblendit. Citovaná práce je zaměřena na rudní akcesorie ve světlé varietě hornblenditu: pyrit, vaesit, chalkopyrit, millerit, polydymit, pentlandit a chromit.

Námi studované horninové vzorky byly odebrány v letech 1996-2002 na zhruba 100 m dlouhém úseku lesní cesty vedoucí od Zámčiska údolím Medvědího dolu, která byla rekonstruována v první polovině 90 . let 20 . století. Ve spodní ćásti úseku vystupuje Hanžlem (1995) popsaný hornblendit, v nejvyšší části pak krupníkové těleso, jehož výchozy byly př́ímo v cestě i v jejím zárezezu. Po dokončení rekonstrukce bylo možno najít vzorky z krupníkového tělesa na svahu pod cestou. Studovány byly hlavně horniny skládající krupníkové těleso, tj. krupník, mastková břidlice, aktinolitická břidlice a chloritická břidlice. V článku jsou však uvedeny i některé údaje o okolním hornblenditu a také o amfibolitech a zelených břidlicích vystupujících $\mathrm{v}$ drobných výchozech ve sledovaném úseku lesní cesty.

Až dosud byla ultramafická hornina $\mathrm{z}$ Medvědího dolu označována jako hornblendit. Její složení však bylo ovlivněno metamorfózou, a proto byl v následujícím textu pro tuto horninu zvolen název metahornblendit, a to zcela v souladu s pojmenováním obdobných hornin z jiných úseků sobotínského masivu (např. Fiala et al. 1980). 


\section{Metodika}

Mineralogicko-petrografické hodnocení vybraných horninových vzorků vycházelo z mikroskopického studia výbrusů a nábrusů $\mathrm{v}$ procházejícím a odraženém světle za použití standardního polarizačního mikroskopu.

Údaje o chemismu 52 horninových vzorků reprezentujících krupníkové těleso a horniny sobotínského masivu $\mathrm{v}$ jeho okolí byly získány pomocí XRF analyzátoru DELTA-PREMIUM v laboratořích firmy URGA, s.r.o. se sídlem v Olomouci (použitou metodiku popisuje Zimák et al. 2016). Chemismus devíti vzorků hornin z krupníkového tělesa a obou hlavních variet metahornblenditu byl stanoven analýzami na mokré cestě (analytik I. Zavřelová, PřF MU Brno), obsahy vybraných stopových prvků (Co, $\mathrm{Cr}, \mathrm{Ni}, \mathrm{V}, \mathrm{Zn}$ ) byly stanoveny metodou AAS (analytik P. Kadlec, PřF MU Brno).

Chemické složení vybraných minerálů bylo studováno metodou EDX na prrístroji CamScan s připojeným EDX analyzátorem Link AN 10000 (28 bodových analýz, analytik V. Vávra, PřF MU Brno) a metodou WDX pomocí elektronového mikroanalyzátoru Cameca SX100 (49 bo- dových analýz, analytici P. Gadas a J. Haifler, PřF MU Brno). Výsledky reprezentativních WDX analýz amfibolů, chloritů a mastku jsou uvedeny v tabulce $3 \mathrm{a} 4$. V prŕípadě amfibolů byly hodnoty apfu vypočteny na bázi 23 atomů kyslíku, poměr mezi $\mathrm{Fe}^{3+}$ a $\mathrm{Fe}^{2+}$ kalkulován na základě $\mathrm{T}+\mathrm{C}=15$. Údaje o chemismu ostatních minerálů jsou pouze stručně komentovány $\mathrm{v}$ textu.

\section{Výsledky \\ Stavba krupníkového tělesa a základní údaje o okolním metahornblenditu}

Krupníkové těleso vystupuje uvnitř metahornblenditu, jenž byl ve studovaném profilu zastižen v nepravé mocnosti $44 \mathrm{~m}$ (pravá je cca $20 \mathrm{~m}$ ), z toho na krupníkové těleso připadají $4 \mathrm{~m}$ (nepravé mocnosti, pravá jsou necelé $2 \mathrm{~m}$ ). Ve směru od podloží do nadloží zde byly rozlišeny tyto horninové typy:

1) tmavý metahornblendit,

2) aktinolit-mastková břidlice se šmouhami bohatými chloritem, místy přecházející do mastek-aktinolitické nebo chlorit-aktinolitické břidlice,

Tab. 1: Chemismus hornin krupníkového tělesa a hornin vystupujících v jeho okolí, XRF analýza (celkové železo uvedeno jako $\mathrm{Fe}_{2} \mathrm{O}_{3}, \mathrm{n}=$ počet vzorků, $\mathrm{x}=$ průměr).

Tab. 1: Chemical composition of rocks of the soapstone body (upper half of the Table) and rocks outcropping in its vicinity (lower half), XRF analysis (total irom is presented as $\mathrm{Fe}_{2} \mathrm{O}_{3}, \mathrm{n}=$ number of samples, $\mathrm{x}=$ average).

\begin{tabular}{|c|c|c|c|c|c|c|c|c|c|c|c|c|}
\hline & \multicolumn{3}{|c|}{$\begin{array}{c}\text { krupník } \\
(\mathrm{n}=6)\end{array}$} & \multicolumn{3}{|c|}{$\begin{array}{l}\text { mastková břidlice } \\
\qquad(\mathrm{n}=5)\end{array}$} & \multicolumn{3}{|c|}{$\begin{array}{l}\text { aktinolitická břidlice } \\
\qquad(\mathrm{n}=4)\end{array}$} & \multicolumn{3}{|c|}{$\begin{array}{l}\text { chloritická břidlice } \\
\qquad(\mathrm{n}=8)\end{array}$} \\
\hline & $\min$. & $\max$. & $\mathrm{x}$ & $\min$. & max. & $\mathrm{x}$ & $\min$. & max. & $\mathrm{x}$ & min. & $\max$. & $\mathrm{x}$ \\
\hline $\mathrm{SiO}_{2}(\mathrm{hm} . \%)$ & 51,6 & 64,8 & 57,9 & 55,1 & 62,2 & 58,2 & 45,4 & 48,5 & 47,2 & 26,8 & 55,5 & 39,7 \\
\hline $\mathrm{TiO}_{2}$ (hm. \%) & $<0,07$ & $<0,07$ & - & $<0,07$ & $<0,07$ & - & $<0,07$ & 0,20 & - & 0,28 & 1,06 & 0,71 \\
\hline $\mathrm{Al}_{2} \mathrm{O}_{3}(\mathrm{hm} . \%)$ & 2,5 & 3,7 & 3,1 & 1,9 & 2,7 & 2,3 & 3,2 & 4,9 & 3,9 & 6,6 & 17,3 & 10,4 \\
\hline $\mathrm{Fe}_{2} \mathrm{O}_{3}(\mathrm{hm} . \%)$ & 5,1 & 7,5 & 6,2 & 4,3 & 7,1 & 5,5 & 7,1 & 8,2 & 7,6 & 8,0 & 12,7 & 10,2 \\
\hline $\mathrm{Cr}_{2} \mathrm{O}_{3}(\mathrm{hm} . \%)$ & 0,11 & 0,26 & 0,19 & 0,11 & 0,20 & 0,15 & 0,10 & 0,21 & 0,13 & $<0,01$ & 0,23 & 0,06 \\
\hline $\mathrm{MgO}$ (hm. \%) & 27,8 & 31,0 & 29,1 & 24,7 & 31,9 & 28,2 & 17,8 & 19,7 & 18,9 & 12,1 & 25,2 & 18,1 \\
\hline $\mathrm{CaO}(\mathrm{hm} . \%)$ & 0,5 & 3,4 & 1,2 & 2,0 & 7,3 & 4,2 & 9,6 & 10,2 & 9,9 & 0,5 & 8,5 & 4,9 \\
\hline $\mathrm{MnO}$ (hm. \%) & 0,08 & 0,11 & 0,09 & 0,08 & 0,13 & 0,11 & 0,16 & 0,24 & 0,18 & 0,10 & 0,23 & 0,16 \\
\hline $\mathrm{Sr}(\mathrm{ppm})$ & 9 & 50 & 19 & 10 & 19 & 13 & 15 & 32 & 21 & 7 & 108 & 35 \\
\hline $\mathrm{Zr}(\mathrm{ppm})$ & 18 & 43 & 31 & $<3$ & 28 & 10 & $<3$ & 36 & 13 & 17 & 223 & 52 \\
\hline $\mathrm{Co}(\mathrm{ppm})$ & 37 & 55 & 46 & $<10$ & 39 & 28 & $<10$ & 41 & - & $<10$ & 49 & - \\
\hline $\mathrm{Ni}(\mathrm{ppm})$ & 1918 & 2456 & 2211 & 1253 & 1962 & 1591 & 245 & 1357 & 1005 & $<10$ & 234 & 117 \\
\hline $\mathrm{Cu}(\mathrm{ppm})$ & $<10$ & $<10$ & - & $<10$ & $<10$ & - & $<10$ & $<10$ & - & $<10$ & 54 & - \\
\hline Zn (ppm) & 36 & 68 & 49 & 54 & 70 & 60 & 51 & 77 & 66 & 47 & 111 & 83 \\
\hline
\end{tabular}

\begin{tabular}{|c|c|c|c|c|c|c|c|c|c|c|c|c|}
\hline & \multicolumn{3}{|c|}{$\begin{array}{l}\text { tmavý metahornblendit } \\
\qquad(\mathrm{n}=8)\end{array}$} & \multicolumn{3}{|c|}{$\begin{array}{l}\text { světlý metahornblendit } \\
\qquad(\mathrm{n}=8)\end{array}$} & \multicolumn{3}{|c|}{$\begin{array}{l}\text { amfibolit } \\
(\mathrm{n}=9)\end{array}$} & \multicolumn{3}{|c|}{$\begin{array}{l}\text { zelená břidlice } \\
\qquad(\mathrm{n}=4)\end{array}$} \\
\hline & $\min$. & max. & $\mathrm{x}$ & $\min$. & $\max$. & $\mathrm{x}$ & $\min$. & max. & $\mathrm{x}$ & $\min$. & max. & $\mathrm{x}$ \\
\hline $\mathrm{SiO}_{2}$ (hm. \%) & 43,0 & 47,6 & 45,6 & 45,2 & 55,9 & 49,1 & 34,2 & 46,6 & 41,4 & 44,7 & 61,5 & 49,7 \\
\hline $\mathrm{TiO}_{2}(\mathrm{hm} . \%)$ & 0,17 & 0,44 & 0,31 & $<0,07$ & 0,09 & - & 0,62 & 1,19 & 0,84 & 0,53 & 3,21 & 2,18 \\
\hline $\mathrm{Al}_{2} \mathrm{O}_{3}(\mathrm{hm} . \%)$ & 4,1 & 6,2 & 5,0 & 2,4 & 4,5 & 3,1 & 9,1 & 13,8 & 10,8 & 10,3 & 13,9 & 11,4 \\
\hline $\mathrm{Fe}_{2} \mathrm{O}_{3}(\mathrm{hm} . \%)$ & 7,1 & 9,7 & 8,4 & 5,2 & 6,1 & 5,7 & 7,9 & 12,2 & 9,9 & 4,5 & 12,1 & 9,8 \\
\hline $\mathrm{Cr}_{2} \mathrm{O}_{3}$ (hm. \%) & 0,11 & 0,20 & 0,15 & 0,16 & 0,30 & 0,22 & 0,01 & 0,12 & 0,06 & $<0,01$ & 0,04 & 0,01 \\
\hline $\mathrm{MgO}(\mathrm{hm} . \%)$ & 15,3 & 19,0 & 17,3 & 20,4 & 25,9 & 22,4 & 9,2 & 13,9 & 11,4 & $<2,0$ & 6,2 & 4,1 \\
\hline $\mathrm{CaO}$ (hm. \%) & 10,5 & 13,5 & 11,3 & 8,9 & 11,4 & 10,3 & 5,9 & 8,0 & 6,5 & 2,9 & 6,5 & 5,0 \\
\hline $\mathrm{MnO}$ (hm. \%) & 0,15 & 0,18 & 0,17 & 0,19 & 0,23 & 0,21 & 0,11 & 0,21 & 0,15 & 0,06 & 0,23 & 0,17 \\
\hline $\mathrm{Sr}(\mathrm{ppm})$ & 26 & 60 & 36 & 20 & 29 & 25 & 49 & 311 & 144 & 286 & 614 & 512 \\
\hline $\mathrm{Zr}(\mathrm{ppm})$ & 12 & 23 & 16 & $<3$ & 18 & - & 17 & 121 & 40 & 129 & 264 & 210 \\
\hline $\mathrm{Co}(\mathrm{ppm})$ & $<10$ & 56 & 37 & $<10$ & 40 & 26 & $<10$ & 48 & 25 & $<10$ & 42 & - \\
\hline $\mathrm{Ni}(\mathrm{ppm})$ & 158 & 303 & 238 & 1360 & 1826 & 1599 & $<10$ & 215 & 104 & $<10$ & 107 & - \\
\hline $\mathrm{Cu}(\mathrm{ppm})$ & $<10$ & 51 & - & $<10$ & 51 & 16 & $<10$ & 262 & 94 & $<10$ & 143 & - \\
\hline $\mathrm{Zn}(\mathrm{ppm})$ & 34 & 70 & 59 & 48 & 70 & 61 & 44 & 99 & 70 & 32 & 116 & 88 \\
\hline
\end{tabular}


3) chlorit-mastková břidlice,

4) mastková břidlice až krupník s hojnými porfyroblasty karbonátu (ve výchozech silně limonitizovaného nebo zcela vylouženého),

5) chloritická břidlice,

6) tmavý metahornblendit.

Tektonicky postižený (kataklazovaný, zbřidličnatělý) a mastkem prostoupený metahornblendit byl zjištěn v úzkých zónách vně krupníkového tělesa. Světlá varieta metahornblenditu vystupuje uvnitř tmavého metahornblenditu. Není zde prŕliš hojná, ve studovaném výchozu byla zastižena v délce cca $2 \mathrm{~m}$. Vzájemný prostorový vztah

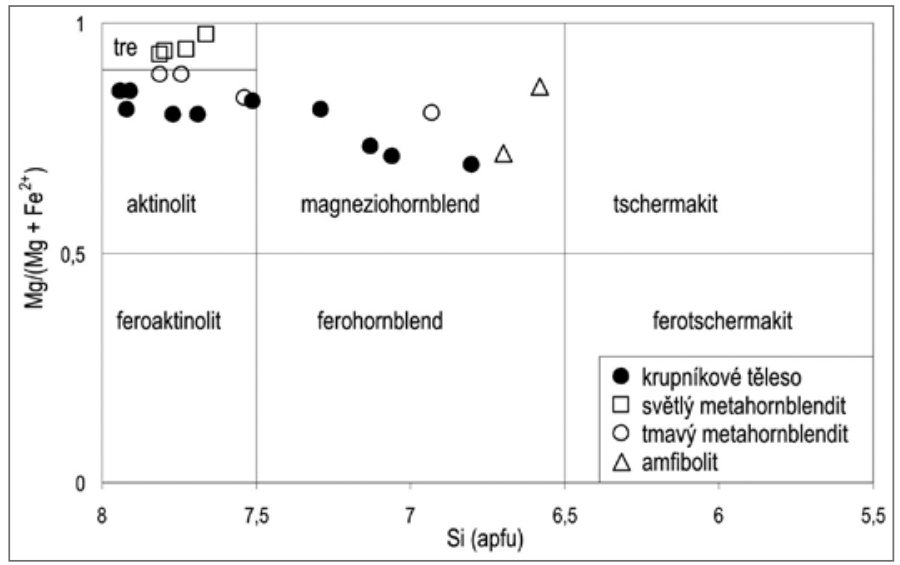

Obr. 1: Analyzované amfiboly v klasifikačním diagramu podle Leakeho (1978).

Fig. 1: Analysed amphiboles in classification diagram by Leake (1978). světlé a tmavé variety není jasný. Jejich vzájemný kontakt či přechod nebyl ve výchozu zastižen, a ani nebyl pozorován na horninových fragmentech v prostoru lokality.

Celkový chemismus tmavého a světlého metahornblenditu je zřejmý $z$ údajů v tabulkách 1 a 2 . Výrazně převažující složkou v obou varietách je amfibol, nejhojnějšími akcesoriemi jsou rutil, „leukoxen“ a apatit, v proměnlivém množství je přítomen křemen, plagioklas, karbonát, biotit a minerál zoisit-epidotové skupiny. Ve světlé varietě se místy hojně vyskytují sulfidy (studované Fojtem a Vávrou 1997), provázené chromitem.

Reprezentativní WDX analýzy amfibolu z obou variet metahornblenditu jsou uvedeny v tabulce 3 . Výsledky všech WDX analýz amfibolu ze světlého metahornblenditu odpovídají tremolitu (obr. 1). Individua amfibolu tvořícího světlý metahornblendit se v BSE obrazu jeví jako víceméně homogenní. $\mathrm{V}$ případě amfibolu $\mathrm{z}$ tmavého metahornblenditu však BSE obraz ukazuje na značnou proměnlivost chemismu. $\mathrm{V}$ řezech individui amfibolu lze pozorovat nepravidelně omezené světlejší a tmavší partie, jen někdy náznak zonálnosti (světlejší jádro, tmavší okraj). Tmavší partie odpovídají aktinolitu (tab. 3, anal. č. 2 a 3), světlejší aktinolitu nebo magneziohornblendu (tab. 3, anal. č. 1).

\section{Složení krupníkového tělesa}

Celkový chemismus hlavních horninových typů krupníkového tělesa (krupník, mastková břidlice, aktinolitická břidlice a chloritická břidlice) je zřejmý $\mathrm{z}$ údajů $\mathrm{v}$ tabulkách 1 a 2, umožňujících srovnání s chemismem obou hlavních variet metahornblenditu a dalších hornin sobotínského masivu $\mathrm{v}$ prostoru lokality (amfibolit, zelená břidlice). $\mathrm{V}$ horninách krupníkového tělesa jsou jako podstatná složka přítomny pouze čtyři minerály - mastek, chlorit, amfibol a dolomit, jejichž kvantitativní poměr určuje petrografické zařazení horniny.

Mastek je šedobílý, místy lehce nazelenalý, zpravidla jemně šupinkovitý. Obsahuje malou příměs $\mathrm{Fe}$ (tab. 4). Jemně šupinkovitý, místy však i lupenitý chlorit je zbarven tmavě zeleně až černozeleně. $\mathrm{V}$ jeho struktuře výrazně převažuje Mg nad Fe (zhruba trojnásobně - viz tab. 4), podle klasifikace doporučované IMA jde tedy o klinochlor, v klasifikaci Melky (1965) v souboru šestnácti analyzovaných chloritů patnáct odpovídá klinochloru, jeden penninu (parametry Melkovy klasifikace: 
$\mathrm{F} / \mathrm{FM}=0,14-0,27, \mathrm{Si}=$ 2,75-3,15 při přepočtu na 14 atomů kyslíku).

Amfibol má prizmatický habitus, délka jeho stébel někdy dosahuje až $15-20 \mathrm{~mm}$. Je zpravidla světle zelený (barvou se podobá amfibolu ze světlého hornblenditu), někdy je tmavě zelený (např. $\mathrm{v}$ břidlici tvořené dominantně chloritem a amfibolem). Z BSE obrazu amfibolů z krupníkového tělesa je často zřejmá jejich chemická nehomogenita. $\mathrm{V}$ horninách s vysokým podílem mastku nebo chloritu složení amfibolu odpovídá aktinolitu (tab. 3 , anal. č. 12), v němž však často bývají ostř̀ omezené uzavřeniny magneziohornblendu (v BSE světlejší, anal. č. 11). Okrajové partie zrn aktinolitu jsou ně$k d y$ přeměněny na jehličkovitý až vláknitý tremolit. V aktinolitické břidlici běžně dochází k obrůstání (či zatlačování) magneziohornblendu (anal. č. 6) aktinolitem (anal. č. 7), oba amfiboly se na složení amfibolových individuí a agregátů $\mathrm{v}$ aktinolitických břidlicích podílejí podstatnou měrou. Složení amfibolů v horninách krupníkového tělesa je zřejmé z obrázku 1, jenž je založen na výsledcích WDX analýz (přepočtem údajů $\mathrm{z}$ EDX analýz byly získány obdobné hodnoty poměru $\mathrm{Mg} /\left(\mathrm{Mg}+\mathrm{Fe}^{2+}\right)$, avšak o něco vyšší počty atomů Si na vzorcovou jednotku, někdy i mírně nad hodnotou 8). Pro srovnání byly do obrázku 1 vyneseny i údaje o chemismu amfibolu $\mathrm{z}$ amfibolitu vystupujícího v blízkosti krupníkového tělesa.

Krupníky jsou tvořeny dominantně mastkem a karbonátem, jehož množství v nezvětralé hornině lze odhadnout na až 25-30 obj. \%. EDX analýzy karbonátu z krupníku a chlorit-mastkové břidlice shodně potvrdily,
Tab. 3: Reprezentativní WDX analýzy amfibolu (hornina: 1 až 3 = tmavý metahornblendit, 4 a 5 = světlý metahornblendit, 6 až 8 = aktinolitická břidlice, 9 a 10 = aktinolit-chloritická břidlice, 11 a 12 metahornblendite, 6 to $8=$ actinolite schist, $9,10=$ actinolite-chlorite schist, 11, $12=$ chlorite schist) .

\begin{tabular}{|c|c|c|c|c|c|c|c|c|c|c|c|c|}
\hline \multirow[b]{2}{*}{ anal. č. } & \multicolumn{3}{|c|}{$\begin{array}{l}\text { tmavý metahorn- } \\
\text { blendit }\end{array}$} & \multicolumn{2}{|c|}{$\begin{array}{l}\text { světlý meta- } \\
\text { hornblendit }\end{array}$} & \multicolumn{7}{|c|}{ horniny krupníkového tělesa } \\
\hline & 1 & 2 & 3 & 4 & 5 & 6 & 7 & 8 & 9 & 10 & 11 & 12 \\
\hline $\mathrm{SiO}_{2}$ (hm. \%) & 49,15 & 56,00 & 56,64 & 57,27 & 56,55 & 46,86 & 56,93 & 53,07 & 49,92 & 54,92 & 49,01 & 55,16 \\
\hline $\mathrm{TiO}_{2}$ (hm. \%) & 0,49 & 0,03 & 0 & 0,02 & 0,02 & 0,53 & 0,02 & 0,11 & 0,39 & 0,04 & 0,44 & 0,05 \\
\hline $\mathrm{P}_{2} \mathrm{O}_{5}$ (hm. \%) & 0,07 & 0 & 0 & 0,02 & 0 & 0,04 & 0,02 & 0,01 & 0 & 0,05 & 0,02 & 0,04 \\
\hline $\mathrm{Al}_{2} \mathrm{O}_{3}(\mathrm{hm} . \%)$ & 8,44 & 1,74 & 1,38 & 1,28 & 2,14 & 10,20 & 1,07 & 4,51 & 7,86 & 3,39 & 7,25 & 2,23 \\
\hline $\mathrm{Cr}_{2} \mathrm{O}_{3}(\mathrm{hm} . \%)$ & 0,13 & 0,08 & 0,01 & 0,18 & 0,65 & 0,03 & 0,02 & 1,39 & 0,05 & 0 & 0,07 & 0,03 \\
\hline $\mathrm{Sc}_{2} \mathrm{O}_{3}(\mathrm{hm} . \%)$ & nest. & nest. & nest. & nest. & nest. & 0 & 0 & 0 & 0 & 0 & 0,07 & 0,10 \\
\hline $\mathrm{V}_{2} \mathrm{O}_{3}(\mathrm{hm} . \%)$ & 0,03 & 0,02 & 0,02 & 0,01 & 0,03 & 0,01 & 0,06 & 0,02 & 0,03 & 0,08 & 0,08 & 0,04 \\
\hline $\mathrm{Fe}_{2} \mathrm{O}_{3}(\mathrm{hm} . \%)$ & 4,54 & 3,12 & 2,27 & 2,58 & 5,01 & 0,62 & 0 & 0 & 0 & 0 & 0,92 & 0 \\
\hline $\mathrm{FeO}$ (hm. \%) & 6,73 & 4,49 & 4,56 & 2,44 & 0,98 & 11,04 & 6,28 & 6,65 & 10,31 & 8,05 & 11,35 & 8,45 \\
\hline $\mathrm{MgO}(\mathrm{hm} . \%)$ & 15,59 & 19,87 & 20,29 & 21,62 & 21,05 & 14,08 & 19,73 & 17,75 & 15,45 & 18,05 & 15,30 & 18,59 \\
\hline $\mathrm{MnO}(\mathrm{hm} . \%)$ & 0,23 & 0,17 & 0,18 & 0,28 & 0,25 & 0,29 & 0,17 & 0,15 & 0,22 & 0,18 & 0,31 & 0,31 \\
\hline $\mathrm{NiO}$ (hm. \%) & 0,05 & 0,05 & 0,01 & 0,11 & 0,12 & 0,05 & 0 & 0,13 & 0,01 & 0 & 0,04 & 0,02 \\
\hline $\mathrm{CaO}$ (hm. \%) & 11,89 & 12,66 & 12,94 & 12,97 & 12,34 & 12,17 & 12,82 & 12,52 & 12,63 & 12,52 & 11,89 & 12,33 \\
\hline $\mathrm{ZnO}$ (hm. \%) & 0,03 & 0 & 0,03 & 0,01 & 0,04 & 0,10 & 0,10 & 0 & 0,05 & 0,06 & 0,03 & 0 \\
\hline $\mathrm{K}_{2} \mathrm{O}(\mathrm{hm} . \%)$ & 0,20 & 0,05 & 0,03 & 0,03 & 0,07 & 0,20 & 0,08 & 0,06 & 0,17 & 0,07 & 0,19 & 0,01 \\
\hline $\mathrm{Na} 2 \mathrm{O}(\mathrm{hm} . \%)$ & 1,60 & 0,40 & 0,17 & 0,20 & 0,37 & 1,30 & 0,20 & 0,60 & 0,87 & 0,62 & 1,18 & 0,31 \\
\hline $\mathrm{F}(\mathrm{hm} . \%)$ & 0,09 & 0,07 & 0,08 & 0,15 & 0,12 & 0,13 & 0,12 & 0,16 & 0,12 & 0,11 & 0,12 & 0,09 \\
\hline $\mathrm{Cl}$ (hm. \%) & 0,01 & 0 & 0 & 0,01 & 0 & 0 & 0 & 0 & 0 & 0 & 0,01 & 0 \\
\hline $\mathrm{O}=\mathrm{F}(\mathrm{hm} . \%)$ & $-0,04$ & $-0,03$ & $-0,03$ & $-0,06$ & $-0,05$ & $-0,05$ & $-0,05$ & $-0,07$ & $-0,05$ & $-0,05$ & $-0,05$ & $-0,04$ \\
\hline $\mathrm{O}=\mathrm{Cl}(\mathrm{hm} . \%)$ & 0 & 0 & 0 & 0 & 0 & 0 & 0 & 0 & 0 & 0 & 0 & 0 \\
\hline suma (hm. \%) & 99,23 & 98,72 & 98,57 & 99,11 & 99,69 & 97,59 & 97,58 & 97,06 & 98,03 & 98,09 & 98,23 & 97,72 \\
\hline $\mathrm{Si}^{4+}$ & 6,93 & 7,74 & 7,81 & 7,79 & 7,66 & 6,80 & 7,94 & 7,51 & 7,13 & 7,69 & 7,06 & 7,77 \\
\hline $\mathrm{Ti}^{4+}$ & 0,05 & 0 & 0 & 0 & 0 & 0,06 & 0 & 0,01 & 0,04 & 0 & 0,05 & 0,01 \\
\hline $\mathrm{P}^{5+}$ & 0,01 & 0 & 0 & 0 & 0 & 0,01 & 0 & 0 & 0 & 0,01 & 0 & 0,01 \\
\hline $\mathrm{Al}^{3+}$ & 1,40 & 0,28 & 0,22 & 0,20 & 0,34 & 1,74 & 0,18 & 0,75 & 1,32 & 0,56 & 1,23 & 0,37 \\
\hline $\mathrm{Cr}^{3+}$ & 0,01 & 0,01 & 0,00 & 0,02 & 0,07 & 0 & 0 & 0,16 & 0,01 & 0 & 0,01 & 0 \\
\hline $\mathrm{Sc}^{3+}$ & - & - & - & - & - & 0 & 0 & 0 & 0 & 0 & 0,01 & 0,01 \\
\hline $\mathrm{V}^{3+}$ & 0,00 & 0,00 & 0,00 & 0,00 & 0,00 & 0 & 0,01 & 0 & 0 & 0,01 & 0,01 & 0,01 \\
\hline $\mathrm{Fe}^{3+}$ & 0,48 & 0,33 & 0,24 & 0,26 & 0,51 & 0,07 & 0 & 0 & 0 & 0 & 0,10 & 0 \\
\hline $\mathrm{Fe}^{2+}$ & 0,79 & 0,52 & 0,53 & 0,28 & 0,11 & 1,34 & 0,73 & 0,79 & 1,23 & 0,94 & 1,37 & 1,00 \\
\hline $\mathrm{Mg}^{2+}$ & 3,28 & 4,09 & 4,17 & 4,39 & 4,25 & 3,04 & 4,10 & 3,74 & 3,29 & 3,77 & 3,29 & 3,90 \\
\hline $\mathrm{Mn}^{2+}$ & 0,03 & 0,02 & 0,02 & 0,03 & 0,03 & 0,04 & 0,02 & 0,02 & 0,03 & 0,02 & 0,04 & 0,04 \\
\hline $\mathrm{Ni}^{2+}$ & 0,01 & 0,01 & 0,00 & 0,01 & 0,01 & 0,01 & 0 & 0,02 & 0 & 0 & 0,01 & 0 \\
\hline $\mathrm{Ca}^{2+}$ & 1,80 & 1,88 & 1,91 & 1,89 & 1,79 & 1,89 & 1,92 & 1,90 & 1,93 & 1,88 & 1,84 & 1,86 \\
\hline $\mathrm{Zn}^{2+}$ & 0 & 0 & 0 & 0 & 0 & 0,01 & 0,01 & 0 & 0,01 & 0,01 & 0 & 0 \\
\hline $\mathrm{K}^{+}$ & 0,04 & 0,01 & 0,01 & 0,01 & 0,01 & 0,04 & 0,01 & 0,01 & 0,03 & 0,01 & 0,04 & 0 \\
\hline $\mathrm{Na}^{+}$ & 0,44 & 0,11 & 0,04 & 0,05 & 0,10 & 0,37 & 0,05 & 0,17 & 0,24 & 0,17 & 0,33 & 0,09 \\
\hline $\mathrm{F}^{-}$ & 0,04 & 0,03 & 0,04 & 0,07 & 0,05 & 0,06 & 0,05 & 0,07 & 0,05 & 0,05 & 0,06 & 0,04 \\
\hline $\mathrm{Cl}^{-}$ & 0 & 0 & 0 & 0 & 0 & 0 & 0 & 0 & 0 & 0 & 0 & 0 \\
\hline $\mathrm{O}^{2-}$ & 22,96 & \begin{tabular}{|l}
22,97 \\
\end{tabular} & 22,96 & 22,93 & 22,95 & 22,94 & 22,95 & 22,93 & 22,95 & 22,95 & 22,94 & 22,96 \\
\hline
\end{tabular}

že jde o dolomit s $0,06 \mathrm{Fe}^{2+}$ apfu a $0,02 \mathrm{Mn}^{2+}$ apfu (přepočet na sumu $\left.\mathrm{R}^{2+}=2,00\right)$.

Pestrou asociaci akcesorických minerálů v horninách krupníkového tělesa tvoří apatit (fluorový), rutil, silně leukoxenizovaný ilmenit, titanit, zirkon, křemen, albit, epidot (někdy se zvýšeným obsahem REE), pyrit a také spinelidy. Ty jsou zastoupeny magnetitem (se zvýšeným obsahem chromu - max. však 6,51 hm. \% $\mathrm{Cr}_{2} \mathrm{O}_{3}$ ) a chromitem, jenž byl zjištěn v aktinolitické břidlici v podobě drobných, převážně izometrických zrn. Analyzovaný chromit obsahuje 45,95 až 48,24 hm. \% $\mathrm{Cr}_{2} \mathrm{O}_{3}$, vyčíslené 
poměry atomových kvocientů: $\mathrm{Cr} /(\mathrm{Cr}+\mathrm{Al})=$ $0,70-0,80, \mathrm{Mg} /\left(\mathrm{Mg}+\mathrm{Fe}^{2+}\right)=0,12-0,14$.

Horninami krupníkového tělesa probíhají drobné žilky alpského typu (zjištěné až při mikroskopickém studiu), tvořené hlavně albitem $\left(\mathrm{An}_{01-02}\right)$, klinochlorem, ale i poměrně hojným epidotem, titanitem a také minerálem skupiny $\mathrm{TiO}_{2}$.

\section{Diskuze}

1. Krupníkové těleso z Medvědího dolu se zastoupením jednotlivých horninových typů nijak podstatně neliší od krupníkových těles $\mathrm{v}$ jiných úsecích sobotínského masivu (např. na klasických lokalitách Zadní Hutisko a Smrčina - viz Kretschmer 1911; Zimák et al. 2002). Nemá však symetricky zonální stavbu, tak typickou pro krupníková tělesa na Sobotínsku, jejichž mastkem bohaté jádro (krupník a mastková břidlice) je lemováno aktinolitickou (příp. tremolitickou) břidlicí, která ve směru k okraji přechází do zóny chloritické břidlice. Zatímco typická krupníková tělesa sobotínského masivu jsou obklopena amfibolity, je výskyt v Medvědím dole situován uvnitř metahornblenditu.

2. Je krajně nepravděpodobné, aby hornblendit jako primární amfibol obsahoval tremolit nebo aktinolit. Lze předpokládat, že amfiboly tohoto složení jsou výsledkem metamorfních nebo alteračních procesů. Amfibol původního ultramafitu by měl určitě vyšší obsah alkalických kovů, hliníku a jistě i vyšší hodnotu $\mathrm{Mg} /\left(\mathrm{Mg}+\mathrm{Fe}^{2+}\right)$. $\mathrm{V}$ některých individuích amfibolu jsou partie tvořené magneziohornblendem, které by mohly být považovány za relikt původního amfibolu, ale spíše se mu svým složením jen více podobají. Lze poznamenat, že amfiboly odpovídající aktinolitu a magneziohornblendu jsou i dominantní složkou metahornblenditu ve výběžku sobotínského masivu na Rudné hoře (Iršová a Zimák 2012) a že tento metahornblendit se zbarvením a stavbou velmi podobá tmavé varietě $\mathrm{z}$ Medvědího dolu. $\mathrm{V}$ prrípadě obou variet metahornblenditu z Medvědího dolu regionální metamorfóza a ani alterace patrně významněji neovlivnily pưvodní stavbu horniny. Kromě změny v chemismu amfibolu došlo během těchto přeměn k leukoxenizaci ilmenitu, ke vzniku karbonátu, minerálu zoisit-epidotové skupiny (na úkor plagioklasu) a některých dalších minoritních složek.

3. Prostorový a genetický vztah mezi světlou a tmavou varietou metahornblenditu $\mathrm{z}$ Medvědího dolu je nejasný. Rozdíly v chemismu obou variet jsou značné (např. obsah $\mathrm{Al}_{2} \mathrm{O}_{3}$ ). Lze jen spekulovat, která $\mathrm{z}$ variet se svým chemismem více blíží původnímu ultramafitu. Pokud je protolit obou variet shodný, pak se mu pravděpodobně více podobá světlá varieta. Tmavá varieta je silněji ovlivněna hydrotermální alterací. To je zřejmé
Tab. 4: Reprezentativní WDX analýzy mastku a chloritu (hornina: 13 a 16 = krupník, 14, 15 a 19 = aktinolit-chloritická břidlice, 17 a $18=$ chloritická břidlice, 20 = aktinolitická břidlice).

Tab. 4: Representative WDX analyses of talc and chlorite (rock: 13, $16=$ soapstone, $14,15,19=$ actinolite-chlorite schist, $17,18=$ chlorite schist, $20=$ actinolite schist $)$.

\begin{tabular}{|c|c|c|c|c|c|c|c|c|}
\hline & \multicolumn{3}{|c|}{ mastek } & \multicolumn{5}{|c|}{ chlorit } \\
\hline anal. č. & 13 & 14 & 15 & 16 & 17 & 18 & 19 & 20 \\
\hline $\mathrm{SiO}_{2}(\mathrm{hm} . \%)$ & 62,78 & 62,12 & 62,50 & 30,84 & 27,93 & 28,66 & 27,69 & 28,07 \\
\hline $\mathrm{TiO}_{2}$ (hm. \%) & 0 & 0,03 & 0 & 0,04 & 0,09 & 0,08 & 0,04 & 0,05 \\
\hline $\mathrm{Al}_{2} \mathrm{O}_{3}(\mathrm{hm} . \%)$ & 0,04 & 0,04 & 0,12 & 16,52 & 20,38 & 19,51 & 21,33 & 21,66 \\
\hline $\mathrm{Cr}_{2} \mathrm{O}_{3}(\mathrm{hm} . \%)$ & 0,02 & 0,01 & 0,01 & 1,42 & 0,02 & 0,07 & 0,08 & 0,43 \\
\hline $\mathrm{V}_{2} \mathrm{O}_{3}(\mathrm{hm} . \%)$ & 0 & 0,03 & 0 & 0,03 & 0,06 & 0,07 & 0,10 & 0,04 \\
\hline $\mathrm{BaO}(\mathrm{hm} . \%)$ & 0 & 0 & 0 & 0,02 & 0,01 & 0 & 0 & 0 \\
\hline $\mathrm{CaO}(\mathrm{hm} . \%)$ & 0 & 0,02 & 0 & 0,03 & 0,01 & 0 & 0,04 & 0,02 \\
\hline $\mathrm{FeO}$ (hm. \%) & 3,26 & 3,95 & 3,79 & 11,13 & 13,77 & 13,88 & 13,75 & 11,10 \\
\hline $\mathrm{MgO}(\mathrm{hm} . \%)$ & 27,38 & 27,02 & 27,01 & 25,19 & 22,11 & 22,45 & 22,00 & 23,42 \\
\hline $\mathrm{MnO}(\mathrm{hm} . \%)$ & 0,03 & 0,03 & 0,01 & 0,10 & 0,20 & 0,16 & 0,18 & 0,18 \\
\hline $\mathrm{NiO}(\mathrm{hm} . \%)$ & 0,35 & 0,21 & 0,33 & 0,25 & 0,07 & 0 & 0,03 & 0,30 \\
\hline $\mathrm{SrO}(\mathrm{hm} . \%)$ & 0 & 0 & 0 & 0 & 0 & 0 & 0,01 & 0 \\
\hline $\mathrm{ZnO}(\mathrm{hm} . \%)$ & 0,02 & 0,02 & 0 & 0 & 0 & 0,03 & 0,09 & 0,08 \\
\hline $\mathrm{K}_{2} \mathrm{O}(\mathrm{hm} . \%)$ & 0,02 & 0,01 & 0,02 & 0,01 & 0,01 & 0,01 & 0 & 0,01 \\
\hline $\mathrm{Na}_{2} \mathrm{O}(\mathrm{hm} . \%)$ & 0,01 & 0,04 & 0,01 & 0,02 & 0,03 & 0,02 & 0,04 & 0 \\
\hline $\mathrm{F}(\mathrm{hm} . \%)$ & 0,10 & 0,09 & 0,07 & 0,02 & 0,02 & 0 & 0 & 0,06 \\
\hline $\mathrm{Cl}$ (hm. \%) & 0 & 0 & 0,01 & 0 & 0 & 0,01 & 0 & 0,02 \\
\hline $\mathrm{O}=\mathrm{F}(\mathrm{hm} . \%)$ & $-0,04$ & $-0,04$ & $-0,03$ & $-0,01$ & $-0,01$ & 0 & 0 & $-0,03$ \\
\hline $\mathrm{O}=\mathrm{Cl}(\mathrm{hm} . \%)$ & 0 & 0 & 0 & 0 & 0 & 0 & 0 & 0 \\
\hline suma (hm. \%) & 93,97 & 93,58 & 93,85 & 85,61 & 84,70 & 84,95 & 85,38 & 85,41 \\
\hline $\mathrm{Si}^{4+}$ & 4,07 & 4,06 & 4,07 & 3,09 & 2,86 & 2,92 & 2,81 & 2,81 \\
\hline $\mathrm{Ti}^{4+}$ & 0 & 0 & 0 & 0 & 0,01 & 0,01 & 0 & 0 \\
\hline $\mathrm{Al}^{3+}$ & 0 & 0 & 0,01 & 1,95 & 2,46 & 2,34 & 2,55 & 2,56 \\
\hline $\mathrm{Cr}^{3+}$ & 0 & 0 & 0 & 0,11 & 0 & 0,01 & 0,01 & 0,03 \\
\hline $\mathrm{V}^{3+}$ & 0 & 0 & 0 & 0 & 0,01 & 0,01 & 0,01 & 0 \\
\hline $\mathrm{Fe}^{2+}$ & 0,18 & 0,22 & 0,21 & 0,93 & 1,18 & 1,18 & 1,17 & 0,93 \\
\hline $\mathrm{Mg}^{2+}$ & 2,65 & 2,63 & 2,62 & 3,76 & 3,37 & 3,41 & 3,33 & 3,50 \\
\hline $\mathrm{Mn}^{2+}$ & 0 & 0 & 0 & 0,01 & 0,02 & 0,01 & 0,02 & 0,02 \\
\hline $\mathrm{Ni}^{2+}$ & 0,02 & 0,01 & 0,02 & 0,02 & 0,01 & 0 & 0 & 0,02 \\
\hline $\mathrm{Zn}^{2+}$ & 0 & 0 & 0 & 0 & 0 & 0 & 0,01 & 0,01 \\
\hline $\mathrm{Na}^{+}$ & 0 & 0,01 & 0 & 0 & 0,01 & 0 & 0,01 & 0 \\
\hline $\mathrm{F}^{-}$ & 0,02 & 0,02 & 0,01 & 0,01 & 0,01 & 0 & 0 & 0,02 \\
\hline $\mathrm{O}^{2-}$ & 10,98 & 10,98 & 10,99 & 13,99 & 13,99 & 14,00 & 14,00 & 13,98 \\
\hline
\end{tabular}

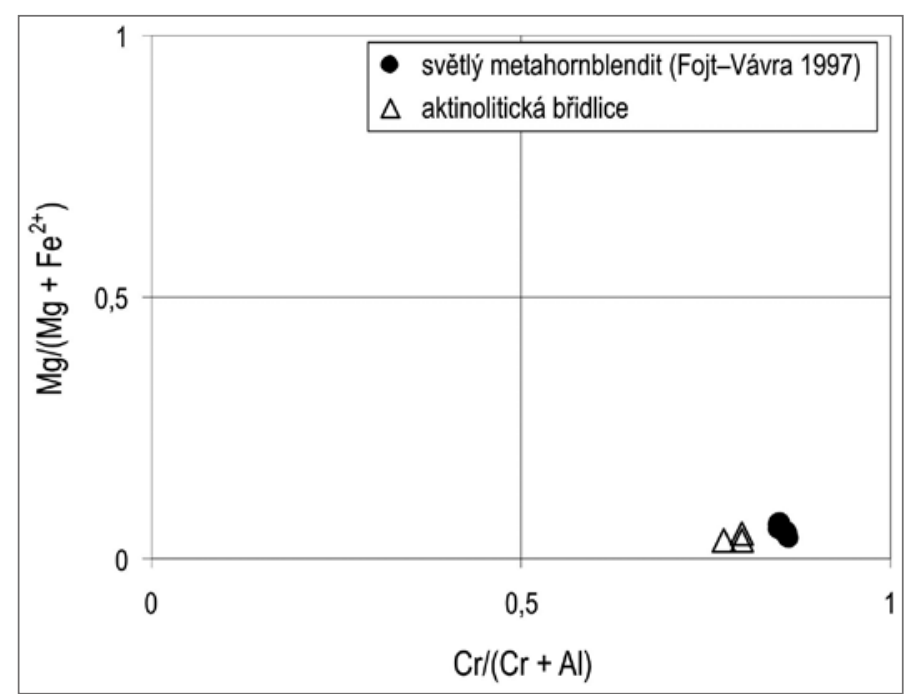

Obr. 2: Pozice spinelidů z Medvědího dolu v klasifikačním diagramu. Fig. 2: Spinelides from Medvědí důl in classification diagram. 
$\mathrm{z}$ př́tomnosti dolomitu a mastku v intergranulárách mezi individui amfibolu i na drobných žilkách (hlavně „vlasových“) a také z tomu odpovídajících zvýšených obsahů $\mathrm{CO}_{2}$ ve výsledcích chemických analýz. S hydrotermální alterací tmavého metahornblenditu možná souvisí i nepatrné zastoupení až absence sulfidických minerálů ve studovaných preparátech, zcela v souladu s relativně nízkými obsahy $\mathrm{S}$ a Ni v této varietě (viz data v tab. 1 a 2).

4. Relativně hojnou akcesorií metahornblenditu i hornin krupníkového tělesa je chromit, jenž byl ze světlého metahornblenditu popsán již Fojtem a Vávrou (1997). Chemismus chromitu z obou rozdílných horninových prostředí je téměř identický (obr. 2). I to by mohlo svědčit o oprávněnosti názoru, že krupníkové těleso v Medvědím dole vzniklo přeměnou metahornblenditu.

\section{Závěr}

Krupníkové těleso vystupující v Medvědím dole je tvořeno: (1) mastkovou břidlicí s variabilním obsahem chloritu a amfibolu, (2) krupníkem (s asociací mastek + dolomit), (3) chloritickou břidlicí a (4) aktinolitickou břidlicí. Toto krupníkové těleso nemá symetricky zonální stavbu charakteristikou pro klasické výskyty na Smrčině a Zadním Hutisku, i když se od nich petrograficky a mineralogicky v zásadě neliší. Vznik krupníkového tělesa v Medvědím dole souvisí s hydrotermální přeměnou metahornblenditu, patrně podél stř̌ižných zón.

\section{Literatura}

Fiala, J. - Jelínek, E. - Pouba, Z. - Poubová, M. - Souček, J. (1980): The geochemistry of the ultrabasic rocks of the Sobotín amphibolite massif (Czechoslovakia). - Neues Jahrbuch für Mineralogie - Abhandlungen, 137, 257-281.

Fojt, B. - Vávra, V. (1997): Rudní akcesorie hornblenditu z údolí Medvědího dolu (Hrubý Jeseník). - Geologické výzkumy na Moravě a ve Slezsku v roce 1996, 105-106.

Hanžl, P. (1995): Hornblendit ze šupiny sobotínského masívu jihovýchodně od Zámčiska. - Geologické výzkumy na Moravě a ve Slezsku v roce 1994, 84 .

Iršová, B. - Zimák, J. (2012): Mineralogie dvou typů železných rud z historických ložisek na Rudné hoře u Vernířovic v Hrubém Jeseníku. - Geologické výzkumy na Moravě a ve Slezsku, 19, 150-153.

Kretschmer, F. (1911): Das metamorphe Diorit- und Gabbromassiv in der Umgebung von Zöptau (Mähren). - Jahrbuch der kaiserlich-königlichen Geologischen Reichsanstalt, 61, 53-180.

Leake, B. E. (1978): Nomenclature of amphiboles. - American Mineralogist, 63, 1023-1052.

Melka, K. (1965): Návrh na klasifikaci chloritových minerálů. - Věstník Ústředního ústavu geologického, 40, $23-27$.

Zimák, J. - Dalajková, K. - Donocik, R. - Krist, P. - Reif, D. - Štelcl, J. - Kopecká, L. (2016): Využitelnost terénních rentgenfluorescenčních analyzátorů ke stanovení chemismu cementářských surovin - na př́kladu velkolomu Mokrá. - Zprávy o geologických výzkumech, 49, 79-82.

Zimák J. - Novotný P. - Fojt B. - Novák M. - Vávra V. - Kopa D. - Losos Z. - Prinzová E. - Skácel J. (2002): Exkurzní průvodce po mineralogických lokalitách na Sobotínsku. UP Olomouc 2002. 